\title{
KONFLIK DAN NEGOSIASI DI DALAM PERSPEKTIF: ARSITEKTUR, SOSIOLOGI, TEKNOLOGI DAN KOMUNIKASI
}

\author{
Santi Isnaini \\ Prodi S2 Media dan Komunikasi Dept. Komunikasi, Universitas Airlangga
}

Disetujui 1 Maret 2018

\begin{abstract}
This article will provide a study of the concepts of conflict and negotiation in various scientific perspectives, which in this context will be seen from the perspective of architecture, sociology, technology and communication. Each perspective has its own perspective in defining and operationalizing a concept of conflict and negotiation, since each formal object of the scientific study has different ontological origins. For this reason through this article will be a basic topic development from various angles of scientific theories that will give a picture of the tradition of each of the scholars. For this reason, a comprehensive discussion of theoretical approaches to the basic topics of conflict and negotiation is required. So in this article the discussion will be divided into two big skeletons. The first will discuss the study of each discipline and its relation to communication. From several perspectives of architecture, sociology, and technology will be presented one by one epistemologis and study. Then from each perspective linked red thread with the tradition of communication science. The second major framework will address topics of conflict and negotiation from the various angles of the scholarship. After the previous discussion has been presented scientific approach, then will be dissected one by one how the scientific approach sees conflict and negotiation. Not only defining the concept of conflict and negotiation, the discussion will also link between each scientific perspective in conflict resolution through negotiation methods. Along with that will be described examples of cases that can clearly illustrate the use of conflict and negotiation topics in various scientific perspectives.
\end{abstract}

Keywords: Conflict, Negotiation, Architecture, Sociology, Techonology, Communication

\begin{abstract}
ABSTRAK
Artikel ini akan memberikan sebuah telaah mengenai konsep konflik dan negosiasi di dalam berbagai perspektif keilmuan, yang dalam konteks ini akan dilihat melalui perspektif arsitektur, sosiologi, teknologi dan komunikasi. Setiap perspektif tersebut memiliki sudut pandangnya masing-masing dalam mendefisinikan maupun mengoperasionalkan sebuah konsep konflik dan negosiasi, mengingat setiap objek formal dari kajian keilmuan tersebut memiliki asal muasal ontologis yang berbeda. Untuk itulah melalui artikel ini akan dilakukan sebuah pengembangan topik dasar dari berbagai macam sudut pandang teori keilmuan yang akan memberikan gambaran tradisi dari masing-masing keilmuan. Untuk itulah diperlukan sebuah pembahasan yang komprehensif menyangkut berbagai pendekatan teoretis yang membahas topik dasar berupa konflik dan negosiasi. Sehingga dalam artikel ini pembahasan akan dibagi menjadi dua kerangka besar. Yang pertama akan membahas mengenai kajian dari masing-masing disiplin beserta kaitannya dengan komunikasi. Dari beberapa perspektif yaitu arsitektur, sosiologi, dan teknologi akan dipaparkan satu per satu epistemologis serta kajiannya. Kemudian dari tiap perspektif dihubungkan benang merahnya dengan tradisi keilmuan komunikasi. Kerangka besar kedua akan membahas topik konflik dan negosiasi dari berbagai sudut keilmuan tersebut. Setelah pada pembahasan sebelumnya telah dipaparkan pendekatan keilmuannya, selanjutnya akan dibedah satu per satu bagaimana pendekatan keilmuan tersebut memandang konflik dan negosiasi. Tidak hanya mendefinisikan konsep konflik dan negosiasi, pembahasan juga akan mengaitkan antara tiap perspektif keilmuan dalam penyelesaian konflik
\end{abstract}

\footnotetext{
*Korespondensi Penulis:

E-mail: santiisnaini@gmail.com
} 
melalui metode negosiasi. Bersamaan dengan itu akan dijabarkan contoh kasus yang dapat menggambarkan secara jelas penggunaan topik konflik dan negosiasi dalam berbagai perspektif keilmuan. Kata kunci: Konflik, Negosiasi, Arsitektur, Sosiologi, Tekonologi, Komunikasi

\section{PENDAHULUAN}

Pentingnya peranan disiplin Ilmu Komunikasi dalam membantu mengatasi pelbagai permasalahan (sosial) makin mengemuka. Berbagai teori komunikasi dapat digunakan untuk memahami fenomena yang ada, meski komunikasi tidak dapat dianggap sebagai panasea untuk mengatasi semua permasalahan yang ada. Hal ini tidak terlepas dari latar belakang disiplin ilmu komunikasi itu sendiri. Sebagai sebuah ilmu, komunikasi diibaratkan sebagai oasis, yang menjadi persimpangan jalan dan tempat perjumpaan berbagai ilmu dalam perjalanan ke tujuan keilmuannya masing-masing. Sebuah fenomena sosial dapat dipahami dari berbagai perspektif disiplin ilmu.

Disiplin komunikasi bersifat interdisipliner. Dimana disiplin komunikasi tumbuh dan terdiri dari berbagai disiplin yang ada, baik dari kelompok humaniora, kelompok ilmu sosial dan perilaku serta kelompok ilmu pasti-alam. Artinya, disiplin ilmu merupakan salah satu sumber perspektif dalam ilmu komunikasi. Beragam disiplin ilmu lain bersama dengan disiplin ilmu komunikasi melahirkan berbagai kajian dan teori yang beragam untuk menganalisis suatu masalah. Seperti halnya kita mengenal istilah komunikasi kesehatan, psikologi komunikasi, sosiologi komunikasi, komunikasi pembangunan, komunikasi kependudukan dan lain sebagainya.

Setiap disiplin ilmu memiliki sudut pandangnya masing-masing dalam mendefisinikan maupun mengoperasionalkan sebuah konsep, yang walaupun secara akademis konsep tersebut menjadi fokus bahasan pada berbagai disiplin ilmu dan memiliki istilah yang dikaji sama, namun ketika dikontekstualisasikan di dalam disiplin ilmu yang berbeda, maka cara pandang dan fokus kajian yang muncul tidak akan sama. Hal ini dimungkinkan mengingat setiap objek formal dari kajian keilmuan tersebut memiliki asal muasal ontologis yang berbeda. Ontologi yang berkaitan dengan asumsi yang berbeda-beda mengenai suatu obyek atau suatu realitas sosial maka akan menimbulkan pemahaman yang berbeda pula akan obyek atau realitas sosial tersebut.

Konflik dan negosiasi merupakan dua istilah yang sering dibicarakan baik di dalam percakapan sehari-hari maupun pada konteks akademik. Secara akademis kedua istilah tersebut menjadi fokus bahasan pada berbagai disiplin ilmu termasuk; Arsitektur, Komunikasi dan Teknologi. Meskipun istilah yang dikaji sama yaitu "konflik dan negosiasi," namun ketika dikontekstualisasikan di dalam disiplin ilmu yang berbeda, maka cara pandang dan fokus kajian yang muncul tidak akan sama. Perbedaan tersebut mereflesikan adanya perbedaan mendasar di antara masingmasing ilmu tersebut, baik secara epitemologis (asal usul pengetahuan) maupun ontologis (sifat dasar dari fokus kajian).

\section{Kajian Masing-Masing Disiplin Serta Kaitannya Dengan Komunikasi}

\section{Arsitektur dan Komunikasi}

Melihat kaitan antara komunikasi dan arsitektur, salah satu cabang dari disiplin keilmuan dari arsitektur adalah komunikasi arsitektur. Dalam perkembangan ilmu arsitektur kemampuan arsitek menyampaikan ide agar dapat dipahami melalui rancangannya menjadi semakin penting. Menurut Edwards Robins (dalam Hutama, 2007), perkembangan metode dan teknik menggambar sebagai instrumen komunikasi ternyata 
berhubungan dengan perkembangan peran arsitek dan efisiensi dan efektifitas proses penciptaan arsitektur yang ingin dicapai. Kesadaran pentingnya komunikasi memunculkan kajian baru di dalam pendidikan arsitektur bernama Teknik Komunikasi Arsitektur (Hutama, 2007):

1. Teknik komunikasi arsitektur adalah seni, metode, atau ketrampilan untuk mengirimkan dan menerima informasi arsitektural agar dapat dipahami oleh pihak yang menjadi sasaran komunikasi.

2. Bentuk komunikasi utama dalam teknik komunikasi arsitektur adalah bentuk visual. Bentuk visual sebaiknya digunakan seaktif mungkin baik itu dalam konteks berkomunikasi atau berpikir. Semakin kuatnya penguasaan bahasa visual akan meningkatkan kemampuan berpikir dalam ruang dan kemampuan untuk mengekspresikan ruang akan menjadi lebih baik.

3. Teknik komunikasi arsitektur menekankan pada pemahaman; obyek dari komunikasi yaitu ruang dan arsitektur, tujuan dan peran dari komunikasi baik sebagai fungsi kultural maupun fungsional.

4. Parameter tujuan dari komunikasi arsitektur adalah ketercapaian tujuan dari komunikasi dan pemahaman partisipan komunikasi terhadap obyek yang dikomunikasikan.

Kembali pada fokus pembelajaran dari arsitektur sendiri yang mengutamakan pada bentuk. Dalam arsitektur, bentuk merupakan bahasa yang digunakan untuk berkomunikasi (Jencks, 1997: 13). Sementara bentuk yang melekat dalam bangunan didefinisikan sebagai gabungan dari bagian-bagian dan unsur-unsur dari bangunan. Dengan melihat bentuk bangunan akan menimbulkan interpretasi di dalam diri pemerhatinya yang bisa saja terkait dengan pencerminan fungsi. Sebagai contoh, bentuk bangunan masjid yang mencerminkan fungsi ibadah. Pencerminan fungsi ini terkait dengan bentuk serta struktur bangunan, kemudian besar skala dan proporsinya, waktu pendirian dan bahan juga turut merefleksikan fungsi tersebut.

Menurut Grosz (2001: 18), ada tiga faktor yang mewujudkan bentuk bangunan. Faktor pertama adalah fungsi yang terkait dengan aktivitas yang dilakukan di dalam bangunan tersebut. Misalnya arsitektur pesawat terbang utamanya pada bentuk ekor dan sayap yang difungsikan untuk menjaga keseimbangan badan pesawat. Fungsi sendiri terbagi lagi menjadi dua kategori. Kategori pertama adalah fungsi utama yang terkait dengan kebutuhan ruang. Misalnya ruang makan yang dikondisikan strukturnya sesuai dengan kebutuhannya, bentuk ruang makan di rumah dan di restoran akan menjadi berbeda bergantung pada kebutuhannya. Kategori kedua adalah fungsi pendukung yang biasanya dihubungkan dengan syaratsyarat bangunan, ruang, ventilasi, pintu dan lain sebagainya.

Faktor selanjutnya adalah simbol.

Simbol ini bisa diinterpretasi secara langsung atau tidak langsung yang secara sengaja dilekatkan pada bangunan dalam rangka mengkomunikasikan fungsi bangunan. Misalnya seperti bentuk donat yang dilekatkan pada counter penjual donat. Simbol berupa bentuk donat dijadikan representasi atas bentuk bangunan yang berfungsi untuk menjual donat. Atau jika melihat monumen-monumen arsitektur yang secara sengaja digunakan sebagai simbolisasi atas suatu budaya. Misalnya patung Selamat Datang yang ada di Jakarta. Fungsi utama dari bentuk bangunan memang secara sengaja mengkomunikasikan keterbukaan manusia Indonesia dalam menerima kedatangan bangsa lain. Bentuk simbol bangunan sendiri terkadang sangat ikonik dengan bentuk yang ia representasikan.

Faktor teknologi struktur dan bahan merupakan faktor terakhir. Dalam pandangan arsitektur, struktur dianggap sebagai media untuk mengungkapkan perasaan estetis yang berangkatnya dari kebenaran struktur (Grosz, 2001: 23). Artinya, sebelum sebuah bangunan berdiri 
harus ada struktur terlebih dahulu. Pentingnya sebuah struktur serta penjelasan filosofisnya untuk memberikan informasi akan fungsi sebuah bentuk bangunan. Selain struktur, teknologi juga terkait dengan bahan yang digunakan untuk membentuk bangunan. Setiap bangunan yang ingin mengkomunikasikan fungsinya harus melalui tahap pengenalan sifat bahan. Karena walaupun bahan yang digunakan sama tapi penyelesaian bangunannya dilakukan dengan cara berbeda akan berdampak pada ekspresi yang berbeda pula. Misalnya kayu yang mudah dibentuk untuk konstruksi paku, meninggalkan kesan yang hangat dan ringan.

Bentuk bangunan juga memiliki fungsi untuk mengekspesikan fungsi yang diemban olah bangunan tersebut. Menurut Louis Sullivan (dalam Grosz, 2001: 43), hal ini disebut sebagai karakter bangunan yang didefinisikan sebagai tampak luar cermin dari fungsi yang ada di dalamnya. Misalnya rumah tinggal yang fungsinya sederhana untuk skala kecil akan berbeda bentuk dengan mall yang memiliki fungsi kompleks untuk skala besar. Sebagai cerminan fungsi, suatu bentuk bangunan harusnya tidak meniru bentuk-bentuk yang sudah ada tapi mencoba untuk membuat suatu bangunan yang bisa membangun persepsi pada orang yang melihatnya sehingga sesuai dengan kesan yang ingin kita tampilkan. Walaupun tidak semua kesan dapat diterapkan dalam bentuk arsitektur, hanya beberapa yang bersifat umum.

Lebih lanjut Sullivan menjelaskan bahwa ada tiga faktor utama yang mempengaruhi karakter bangunan. Faktor pertama adalah berdasarkan ingatan. Bentuk-bentuk bangunan yang sudah sering digunakan akan menimbulkan pola pada ingatan manusia, seperti misalnya kubah bulat yang ada di ingatan individu sebagai bagian dari masjid. Faktor kedua adalah kesan. Bentuk bangunan selalu menimbulkan kesan tertentu karena efek visual yang dihasilkannya saat bersentuhan dengan indera penglihatan. Misalnya garis horizontal tanpa batas seperti yang ada di pantai menimbulkan kesan tenang. Faktor terakhir terkait dengan penyajian fungsional. Karena karakter bangunan dapat timbul dari bentuk dan garis dengan ukuran dasar yang sesuai dengan fungsinya.

Untuk mengkomunikasikan fungsi melalui bentuk bangunan, Grosz (2001: 15) menjelaskan bahwa warna merupakan salah satu komponen penting dalam rangka memperkuat bentuk serta memberikan penjelasan pada individu yang melihatnya. Jika penggunaan warna tidak secara hatihati maka warna bisa merusak bentuk dan citra. Dengan warna dapat menciptakan suasana yang diharapkan oleh pembuat bangunan. Dalam arsitektur, pemilihan warna dominan dan komplemen menjadi salah satu hal penting untuk mengkomunikasikan fungsi bangunan.

Selain warna, gaya juga sebuah komponen yang penting dalam mengkomunikasikan fungsi bangunan. Bisa ditinjau dari iklim, kepribadian, zaman dan kebudayaan, bahan bangunan serta sejarah. Misalnya untuk iklim tropis, gaya overstek atau yang beratap miring, fungsinya untuk menahan hujan dan sinar matahari. Sementara untuk iklim Barat, digunakan kaca untuk menangkap cahaya matahari dan menghindari dingin. Sementara untuk gaya yang berdasar pada kepribadian bisa didasarkan pada pengalaman serta selera dalam memecahkan masalah dari sisi arsitektur. Gaya berdasar bahan misalnya pada arsitektur tradisional dari bahan kayu dan bambu atau arsitektur modern yang berbahan beton dan rangka. Untuk gaya berdasar zaman bisa dilihat pada bentuk bangunan yang bercermin pada gaya bangunan Romawi maupun Yunani. Sementara jika gaya dilandaskan pada sejarah, bisa dilihat pada rumah-rumah gaya kolonial yang menyimbolkan penjajahan barat yang terjadi di Indonesia.

Salah satu elemen penting di dalam mendesain dan mendirikan suatu bangunan adalah ruang (space). Space merupakan tema kajian yang dibahas pada berbagai disiplin ilmu terutama arsitektur. Di dalam konteks arsitektur konsep mengenai ruang berakar dari filosofi Lao Tzu mengenai cara 
untuk menjadi yang berpandangan bahwa ruang yang terkurung di dalam lebih hakiki ketimbang materialnya. Juga pemikiran Aristoteles (384-322), ruang adalah riil sejauh terdapat keluasan berdimensi dengan panjang, lebar, tinggi (atau dalamnya). Brinckmann mendifinisikan tiga konsep ruang: (a) massa skulptural yang berdiri bebas dan dikelilingi oleh ruang, (b) ruang yang dikelilingi massa, dan (c) kulminasi, atau saling-rusuk pada interior. Berbagai elemen dari ruang di dalam arsitektur berfungsi untuk mengkomunikasikan fungsi, kesinambungan, sifat dan filosofi dari bangunan. Posisi ruang di dalam rumah juga mengkomunikasikan fungsi dan tingkatan privasi (the level of accessibility). Contoh lain seperti yang diungkapkan oleh Ching (dalam Guntoro, 2008), empat buah bidang dapat membentuk suatu kawasan ruang dan kawasan visual untuk suatu tempat suci atau bangunan penting yang berdiri sebagai sebuah obyek di dalam rangkuman ruang.

Kajian ruang yang telah menjadi bahasan arsitektur sejak lama, juga menjadi tema bahasan di dalam komunikasi. Salah satu tokohnya adalah Edward Hall (dalam Littlejohn, 2000) yang berteori mengenai proxemics yang mengacu pada penggunaan space di dalam komunikasi. Hall menyatakan proxemics merupakan kajian yang menunjukkan bagaimana manusia secara tidak sadar membuat struktur ruang mikro - jarak antar manusia ketika berkomunikasi, pengorganisasian ruang di rumah dan gedung, juga tata ruang kota. Orang akan cenderung merasa posesif pada beberapa ruang yang dimilikinya seperti kamar, mobil, ataupun halaman. Ketika kita bicara terkadang kita duduk atau berdiri sangat dekat dengan orang yang kita ajak bicara dan pada saat yang lain merasa lebih nyaman untuk menjaga jarak tertentu. Perasaan tersebut menurut Stewart dan Logan (1993), terkait dengan apa yang disebut sebagai proxemics, studi mengenai pengaruh ruang dan jarak bagi komunikasi. Menurut Littlejohn (2000) ketika manusia melakukan komunikasi tatap muka terdapat delapan faktor yang mungkin terkait dengan bagaimana manusia menggunakan space mereka:

1. Posture-sex factors: terkait dengan jenis kelamin dari partisipan dan posisi dasar mereka (berdiri, duduk, dan berbaring).

2. Sociofungal-sociopetal axis: sociofungal berarti interaksi yang tidak suportif dan sociopental berarti komunikasi yang mendukung. Pembicara mungkin saling berhadapan, saling membelakangi, atau menghadap ke arah sudut tertentu, menggambarkan saling mendukung atau tidak.

3. Kinesthetic factors: terkait kedekatan individual terkait dengan kemungkinan saling menyentuh.

4. Touching behavior: orang mungkin terlibat di dalam tindakan menyentuh, berpegangan, saling mendekat dan sebagainya.

5. Visual code: kategori ini termasuk perilaku kontak mata seperti saling pandang langsung dan tidak memandang sama sekali.

6. Thermal Code: terkait dengan kehangatan yang diterima dari partisipan komunikasi yang lain.

7. Olfactory code: termasuk bau yang diterima dari lawan bicara.

8. Voice loudness: kerasnya suara dalam pembicaraan dapat berpengaruh pada ruang antar persona.

Selanjutnya Stewart dan Logan (1993) menyatakan bahwa masing-masing dari kita hidup di dalam ruangan personal, gelembung yang relatif kecil, tidak terlihat, dibawa kemana-mana, dan dapat disesuaikan. Gelembung tersebut kita jaga untuk melindungi diri kita dari ancaman fisik dan emosional. Ukuran gelembung tersebut bervariasi; seberapa jauh kita duduk atau berdiri tergantung pada latar belakang budaya, hubungan dengan orang lain, situasi atau konteks, dan bagaimana perasaan kita pada orang lain pada saat itu. Hall (dalam Stewart dan Logan, 1993) mengidentifikasikan empat jarak yang terdapat di dalam banyak budaya, meskipun 
batasan pada setiap zona bisa berbeda antara budaya yang satu dengan yang lain:

1. Intimate Distance (Bersentuhan sampai 18 inci): Zona ini mulai dengan kontak kulit sampai dengan satu setengah kaki. Biasanya kita mengalami jarak yang terdapat pada zona ini dengan orangorang yang dekat secara emosional, sebagai upaya untuk menenangkan, melindungi, menyentuh dan menunjukkan rasa cinta. Kalau kita terpaksa melakukan zona intim dengan orang asing misalnya pada eskalator, kita cenderung untuk menggunakan tanda non verbal untuk menunjukkan keterpisahan atau ketidaknyamanan seperti menghindari kontak mata, bersedekap tangan atau mungkin meletakkan tas di depan badan kita.

2. Personal Distance (1,5 sampai 4 kaki): jarak ini paling dipilih oleh kebanyakan partner bicara pada seting publik. Biasanya subjek yang saling memiliki ketertarikan personal dan tingkat keterlibatan sedang berbicara pada jarak ini. Bersentuhan masih mungkin tetapi terbatas pada tepukan singkat untuk memberi penekanan atau dukungan.

3. Social Distance (4 sampai 12 kaki): komunikasi bisnis yang tidak bersifat personal biasanya berada pada zona ini. Orang yang bekerja sama atau menghadiri pertemuan yang bersifat sosial cenderung menggunakan zona jarak sosial.

4. Public Distance (12 sampai 25 kaki): jarak terdekat pada zona ini biasanya digunakan pada instruksi atau manajer berbicara dengan kelompok kerja. Jarak yang terjauh pada zona ini biasanya terjadi pada pidato. Ketika kita berkomunikasi pada jarak ini suara kita harus keras atau menggunakan alat pengeras suara. Pada jarak yang jauh ekspresi wajah, gerakan dan bahasa tubuh harus lebih ditampakkan agar bisa memiliki arti bagi yang diajak berkomunikasi.

\section{Sosiologi dan Komunikasi}

Sosiologi berasal dari bahasa Latin yaitu Socius yang berarti kawan, teman sedangkan Logos berarti ilmu pengetahuan (Susanto, 1985: 3). Jadi Sosiologi adalah ilmu pengetahuan tentang masyarakat. Masyarakat adalah sekelompok individu yang mempunyai hubungan, memiliki kepentingan bersama, dan memiliki budaya. Sosiologi hendak mempelajari masyarakat, perilaku masyarakat, dan perilaku sosial manusia dengan mengamati perilaku kelompok yang dibangunnya. Kelompok tersebut mencakup keluarga, suku bangsa, negara, dan berbagai organisasi politik, ekonomi, sosial. Istilah Sosiologi sebagai cabang Ilmu Sosial dicetuskan pertama kali oleh ilmuwan Perancis, bernama August Comte tahun 1842, sehingga Comte dikenal sebagai Bapak Sosiologi.

Selanjutnya Émile Durkheim, seorang ilmuwan sosial Perancis, yang kemudian berhasil melembagakan Sosiologi sebagai disiplin akademis. Sosiologi merupakan sebuah istilah yang berasal dari kata Latin socius yang artinya teman, dan logos dari kata Yunani yang berarti cerita, diungkapkan pertama kalinya dalam buku yang berjudul "Cours De Philosophie Positive" karangan August Comte (17981857). Sosiologi muncul sejak ratusan, bahkan ribuan tahun yang lalu. Namun sosiologi sebagai ilmu yang mempelajari masyarakat baru lahir kemudian di Eropa.

Sejak awal masehi hingga abad 19, Eropa dapat dikatakan menjadi pusat tumbuhnya peradaban dunia, para ilmuwan ketika itu mulai menyadari perlunya secara khusus mempelajari kondisi dan perubahan sosial. Para ilmuwan itu kemudian berupaya membangun suatu teori sosial berdasarkan ciri-ciri hakiki masyarakat pada tiap tahap peradaban manusia.

Menurut Pitirim A Sorokin (dalam Susanto, 1985: 10), sosiologi adalah ilmu yang mempelajari hubungan dan pengaruh timbal balik antara aneka macam gejala sosial (misalnya gejala ekonomi, gejala keluarga, dan gejala moral), sosiologi adalah ilmu yang mempelajari hubungan dan pengaruh timbal balik antara gejala 
sosial dengan gejala non-sosial, dan yang terakhir, sosiologi adalah ilmu yang mempelajari ciri-ciri umum semua jenis gejala-gejala sosial lain. Sementara menurut Selo Sumardjan dan Soelaeman Soemardi, sosiologi adalah ilmu kemasyarakatan yang mempelajari struktur sosial dan prosesproses sosial termasuk perubahan sosial.

Tiga pokok bahasan sosiologi yang utama menurut Ritzer dan Goodman (2004) adalah fakta sosial, tindakan sosial dan realitas sosial. Fakta sosial adalah cara bertindak, berpikir, dan berperasaan yang berada di luar individu dan mempunya kekuatan memaksa dan mengendalikan individu tersebut. Contoh, di sekolah seorang murid diwajibkan untuk datang tepat waktu, menggunakan seragam, dan bersikap hormat kepada guru. Kewajibankewajiban tersebut dituangkan ke dalam sebuah aturan dan memiliki sanksi tertentu jika dilanggar. Dari contoh tersebut bisa dilihat adanya cara bertindak, berpikir, dan berperasaan yang ada di luar individu (sekolah), yang bersifat memaksa dan mengendalikan individu (murid).

Sementara tindakan sosial adalah suatu tindakan yang dilakukan dengan mempertimbangkan perilaku orang lain. Contoh, menanam bunga untuk kesenangan pribadi bukan merupakan tindakan sosial, tetapi menanam bunga untuk diikutsertakan dalam sebuah lomba sehingga mendapat perhatian orang lain, merupakan tindakan sosial. Sementara untuk realitas sosial terkait dengan kemampuan sosiolog untuk menyingkap berbagai tabir dan mengungkap tiap helai tabir menjadi suatu realitas yang tidak terduga. Syaratnya, sosiolog tersebut harus mengikuti aturanaturan ilmiah dan melakukan pembuktian secara ilmiah dan objektif dengan pengendalian prasangka pribadi, dan pengamatan tabir secara jeli serta menghindari penilaian normatif.

Hubungan antara tradisi keilmuan Sosiologi dan Komunikasi pada dasarnya sangat dekat karena Komunikasi sendiri adalah salah satu disiplin ilmu yang dikembangkan dari pendekatan Sosiologi. Salah satu pendekatan keilmuan Sosiologi yang senantiasa didekatkan dengan Komunikasi adalah perspektif interaksionisme yang seringkali disebut sebagai interaksi simbolik. Bagi para ilmuwan tradisi interaksional, proses komunikasi dan pemaknaan dianggap sebagai fokusnya, dan penjelasan kognitif dianggap sebagai fokus keduanya (Littlejohn, 2000:155). Bagi para teoretisi interaksional, makna diciptakan dan dipertahankan melalui kegiatan interaksi dalam suatu kelompok sosial. Interaksi mendirikan, memelihara, dan merubah beberapa konvensi yang ada seperti peranperan, aturan-aturan, norma-norma, dan pemaknaan, yang ada di dalam suatu kelompok sosial atau budaya, dan konvensi baru ini pada akhirnya mendefinisikan realitas dari kultur itu sendiri.

Interaksi simbolik dikarakterisasikan oleh beberapa gagasan pemikiran mengenai komunikasi dan masyarakat. Seperti yang dirangkum oleh Barbara Ballis Ball (dalam Littlejohn, 2000: 157) berikut ini:

1. Individu mengambil keputusan dan bertindak sesuai dengan pengertian subjektifnya mengenai suatu situasi yang mereka temukan sendiri.

2. Kehidupan sosial terdiri atas prosesproses interaksi, daripada struktur, sehingga selalu berubah dengan terusmenerus.

3. Individu mempelajari pengalaman mereka melalui pemaknaan yang ditemukan dalam simbol-simbol dari kelompok primernya, dan bahasa adalah merupakan bagian yang esensial dari kehidupan sosial.

4. Dunia terbentuk dari objek-objek sosial yang diberi nama dan memiliki makna yang ditentukan secara sosial.

5. Tindakan individu didasarkan pada interpretasi pribadinya, yang mana objek-objek dan tindakan yang relevan dalam situasi tersebut diperhitungkan dan ditetapkan.

6. Diri seseorang merupakan suatu objek yang signifikan, dan seperti objekobjek sosial lainnya, didefinisikan 
melalui interaksi sosial dengan orang lain.

Pada dasarnya, pengalaman individu dibentuk melalui proses pemaknaan yang diciptakan dengan penggunaan simbol-simbol saat melakukan aktivitas komunikasi di dalam suatu kelompok. Sehingga cara terbaik untuk mencapai suatu tujuan akan diperoleh dengan berinteraksi dengan orang lain dalam kelompok sosial.

Lebih jauh, paradigma interaksionisme simbolik menganalogikan bahwa dunia yang kita tinggali ini sebagai panggung sandiwara. Setiap peran yang dilekatkan pada individu sudah memiliki skenario dari pola interaksi manusia tiap harinya. Setiap individu yang menyimpang dari skenario pasti memperoleh punishment dari lingkungan sosialnya. Dengan kata lain selalu ada narasi besar dalam dramatisasi kehidupan individu di lingkungan sosialnya.

Kehidupan manusia sendiri senantiasa melibatkan stories (cerita-cerita) yang terkait dengan penggunaan simbol dan penciptaan makna. Dramatisme dibedakan atas ketergantungan kuatnya terhadap theatrical metaphor (metafora teatrikal), dan narasi dikarakterisasikan oleh penggunaannya dalam merangkai suatu cerita. Pergerakan dramaturgi sangat dekat hubungannya dengan interaksi simbolik dan sangat dipengaruhi olehnya. Para dramaturgis melihat individu sebagai aktor dalam panggung metaforis dan memainkan suatu peran. Seperti yang disketsakan oleh Bruce Gronbeck (dalam Littlejohn, 2000: 162) berikut ini:

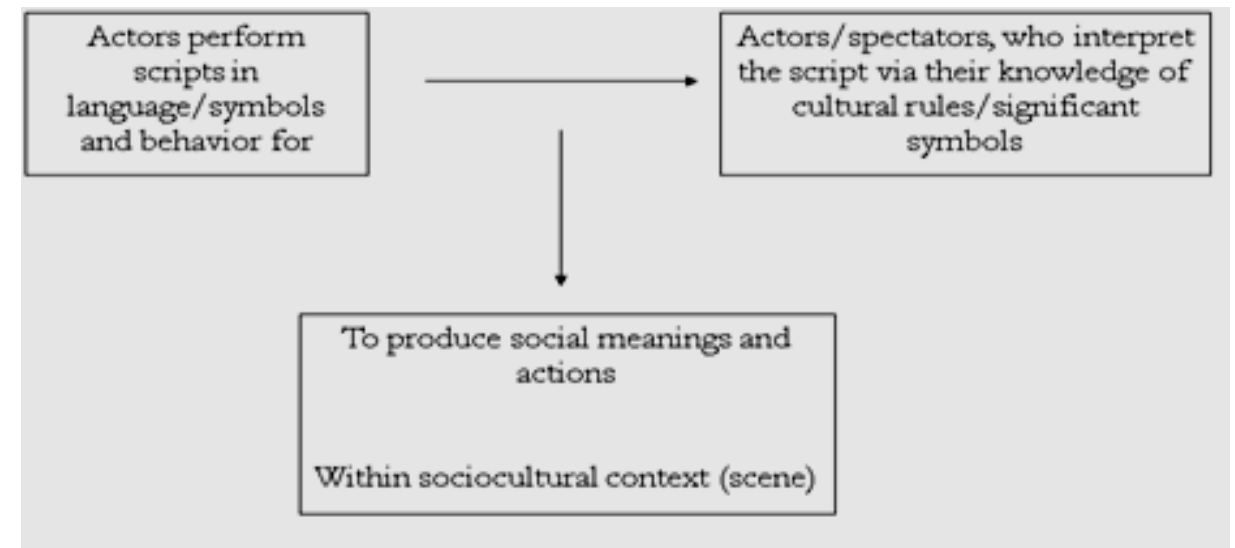

Gambar 1. Dramaturgical Model of Society

Sumber:Littlejohn, 2000:162

Dalam proses penampilan, pemaknaan dan tindakan diproduksi dalam suatu scene (adegan) atau sociocultural context (konteks sosiokultural).

\section{Teknologi dan Komunikasi}

Biasanya bila orang berbicara teknologi, teknologi disebut sebagai alat. Terdapat berbagai teori dan konsep tentang tekonologi, mulai dari yang umum dan luas hingga yang paling spesifik dan sempit. Teknologi berasal dari kata 'technologia', sebuah kata Yunani, yang secara bebas dapat diartikan sebagai 'tindakan membuat atau melakukan keterampilan tertentu (crafting) yang mengacu pada serangkaian proses dan pengetahuan yang digunakan orang untuk memperpanjang kemampuan manusia dan memuaskan kebutuhan serta keinginan manusia'. Dengan kata lain bagaimana manusia memodifikasi lingkungan alam atau sumber daya alam agar sesuai dengan tujuannya. 
Salah satu tokoh yang membahas tekonologi adalah Marshal McLuhan. Konsepnya merupakan salah satu konsep yang paling dikenal di ilmu komunikasi. McLuhan menyebutkan bahwa "Teknologi sama dengan Media". Di sini bukan berarti bahwa media massa yang menentukan segalanya, namun teknologinya yang penting. Secara ringkas terdapat 3 (tiga) thesis McLuhan tentang teknologi:

1. Extension Thesis

Media di sini menurut McLuhan adalah segala sesuatu yang bisa memperpanjang diri kita, memperpanjang kemampuan manusia untuk memenuhi kebutuhan, mengatasi kendala, dan memudahkan hidup. Apa yang tidak bisa kita jangkau bisa dibantu oleh teknologi. Itulah sebabnya teknologi disebut juga sebagai The Extension of Man. Sehingga teknologi di sini bukanlah media massa.

2. Environmental Thesis

Teknologi atau media menciptakan lingkungan, merombak lingkungan hidup lama dan menciptakan lingkungan hidup baru serta mengubah rasa persepsi manusia. Sehingga bisa dikatakan merupakan deterministik karena teknologi menentukan kehidupan manusia, menentukan kebutuhan dan kemajuan manusia sehingga pada akhirnya akan membentuk budaya baru. Dengan begitu, teknologi tidak dapat dibendung.

3. Anti-content $\rightarrow$ Medium is The Message

Di sini, McLuhan mengatakan bahwa content tidak penting, medianya yang penting. Teknologi merupakan media pemuasan diri. Misalnya saja bila kita berbicara jam, bukan jam secara fisik yang penting, melainkan teknologi penunjuk waktunyalah yang penting.

Tokoh lainnya yaitu Arnold Pacey (2000:4-7) mengemukakan satu konsep teknologi yaitu bahwa "peradaban yang menentukan teknologi". Menurutnya teknologi bukannya tidak terbendung dan melihat teknologi harus secara lengkap dari tiga aspek yaitu 'Aspek Kultural', 'Aspek Organisasi', dan 'Aspek Teknis'. Hidup manusia memang melihat teknologi dari aspek teknis. Ini yang sering terlihat jelas dan menjadi makna yang sering kali digunakan ketika berbicara teknologi. Jadi kita sering kali hanya berbicara pengetahuan, keterampilan dan teknik, mesin-mesin, sumber daya, bahan-bahan kimia, produk dan sampah sebagai pembentuk dan penggunaan teknologi. Tapi sebenarnya yang menghidupkan teknologi adalah aspek kultural dan aspek organisasi.

Dalam aspek kultural, terdapat tujuan, nilai, kode etik, kepercayaan akan perkembangan (belief in progress), awareness, dan kreatifitas dalam penggunaan dan penciptaan tekonologi. Perkembangan penggunaan teknologi berhubungan dengan ketepatgunaan sebuah teknologi dalam masyarakat serta kebutuhan masyarakat yang nantinya akan memodifikasi teknologi tersebut. Sebagai contoh teknologi pager di tahun 1990an. Jelas terlihat dari diagram pertumbuhannya yang cenderung stagnan bahwa teknologi ini tidak digunakan secara integral dalam masyarakat. Mestinya hal tersebut menjadi pelajaran bagi perusahaan yang menjual pager untuk memodifikasi teknologinya sehingga adopsi yang menyeluruh bisa terwujud. Tapi keterlambatan dalam proses modifikasi sifatnya bisa fatal. Seperti yang kita lihat sekarang, telepon seluler yang mengadopsi teknologi pager menjadi fitur SMS mengalami pertumbuhan yang luar biasa pesat. Sementara teknologi pager seolah tidak pernah terdengar.

Dalam aspek organisasi, organisasi yang diberikan legitimasi untuk mendiseminasikan teknologi tersebut berperan penting. Semakin baik manajemen sebuah organisasi yang mendiseminasikan teknologi tersebut berimplikasi positif terhadap pertumbuhan penggunaan teknologi itu sendiri. Komponen dalam organisasi yang akan mendukung proyek diseminasi teknologi itu antara lain pekerja, kebijakan-kebijakan organisasional, budaya 
organisasi dan efektivitas serta efisiensi kinerja organisasi.

Pada beberapa kasus, pertumbuhan penggunaan suatu teknologi terjebak di sebuah titik stagnan diakibatkan oleh organisasi yang diberi kewenangan untuk mendiseminasikannya. Contohnya, teknologi anti-virus lokal Indonesia. Mereka rata-rata tidak didiseminasikan menggunakan sebuah organisasi tertentu meskipun secara teknologi tidak kalah dengan anti-virus dari luar negeri. Antivirus Indonesia dinilai memiliki kelebihan jika harus berhadapan dengan virus lokal, berbeda dengan anti-virus luar yang tidak berkutik, namun tanpa adanya manajemen yang tepat dalam mendiseminasikannya teknologi tersebut tidak mengalami pertumbuhan apapun.

Mencermati konsep pokok dan teori yang dikemukakan oleh Marshall McLuhan dan Arnold Pacey, terlihat adanya perbedaan cara pandang dalam melihat teknologi sebagai deterministik (Perspektif Technological Determinism atau Social Construction of Technology).

McLuhan melihat teknologi sebagai yang menentukan kehidupan manusia bahkan dapat membentuk budaya baru. Selain itu, teknologi sebagai instrumen yang bertujuan memudahkan manusia dalam menjalankan kehidupannya memiliki kecenderungan bebas nilai. Di sini sebuah teknologi menjadi determinan utama.

Sebagai contoh, melihat televisi menggunakan kacamata Technological Determinism maka dapat diambil sebuah proposisi bahwa televisi sebagai sebuah bentuk teknologi menjadi determinan utama dalam perubahan sosial. Sehingga bisa dikatakan bahwa hadirnya televisi memberikan katalisator bagi perubahan peradaban masyarakat menuju pola interaksi dan komunikasi yang transformasional. Akibatnya, setiap sendi kehidupan akan berubah seiring dengan perkembangan teknologi tersebut. Dan tidak dapat dipungkiri bahwa perubahan yang merupakan konsekuensi logis dari muncul dan berkembangnya teknologi membawa masyarakat pada sebuah titik baru untuk mendefinisikan ulang strukturnya.

Dilihat dari segi peningkatan adopsi teknologi di berbagai lapisan masyarakat serta perkembangannya ke wilayah-wilayah lain dari suatu daerah, konsep 'The Extension of Man' memiliki pengaruh penting bagi media dan industri komunikasi. Dengan konsep ini, menurut McLuhan, setiap teknologi berubah maka berubah pula 'media' yang diperlukan manusia. Sehingga hidup matinya 'media' tergantung teknologi yang sedang dibutuhkan atau yang sedang sering digunakan.

Sedangkan Pacey memandang bahwa peradaban yang mempengaruhi teknologi. Setiap wilayah kultural memiliki karakteristik masing-masing yang berujung pada kebutuhan yang berbeda dalam menggunakan sebuah teknologi. Banyak faktor sosio-kultural yang harus diperhitungkan secara kualitatif dalam penggunaan teknologi. Selain itu, teknologi dianggap sebagai produk intelektual manusia yang memiliki implikasi secara sosiokultural akibat raison de etre-nya yang tidak bebas nilai. Di sini teknologi dianggap sebagai variabel perantara dari sebuah perubahan sosial.

Dari sisi peningkatan adopsi teknologi di berbagai lapisan masyarakat serta perkembangannya ke wilayah-wilayah lain dari suatu daerah, pada konsep Pacey bahwa 'peradaban mempengaruhi teknologi', dapat terlihat bahwa keterkaitan antara teknologi, praktik penggunaannya, pertumbuhan serta kesempurnaanya dalam suatu lingkup kultural menjadi suatu hal yang problematik. Setiap wilayah kultur yang memiliki karakteristiknya masingmasing memiliki pula kebutuhan yang berbeda dalam penggunaan sebuah teknologi. Organisasi yang memiliki legitimasi terhadap diseminasi sebuah teknologi seringkali menghadapi permasalahan yang seharusnya tidak perlu karena tidak memperhatikan faktor sosiokultural.

Sementara masih dengan contoh televisi, jika teknologi televisi tersebut 
dilihat menggunakan paradigma Social Construction of Technologi niscaya teknologi tersebut muncul akibat kebutuhan manusia untuk mempermudah dirinya dalam menjalani kehidupannya. Walaupun awalnya hanya sekelompok orang yang memanfaatkan teknologi, namun lamakelamaan proses adopsi akan menyentuh setiap sisi kehidupan dalam masyarakat. Namun, sentuhan teknologi ini tidak lantas merubah masyarakat sebagai faktor determinan, masyarakatlah yang mendefinisikan serta mereproduksi realita mengenai teknologi itu sendiri. Nilai-nilai yang dilekatkan pada teknologi, maknanya semua diciptakan oleh anggota masyarakat. Sebab itulah teknologi tidak mungkin bebas nilai.

\section{Konflik dan Negosiasi dalam Berbagai Perspektif Keilmuan}

Setiap kelompok dalam satu bingkai sosial, dimana di dalamnya terjadi interaksi antara satu dengan lainnya, memiliki kecenderungan timbulnya konflik. Dalam setiap pranata sosial maupun kehidupan sehari-hari akan menciptakan beberapa kelompok interaksi yang mana situasi tersebut seringkali dapat memicu terjadinya konflik. Konflik sangat erat kaitannya dengan perasaan manusia, termasuk perasaan diabaikan, disepelekan, tidak dihargai, ditinggalkan, dan juga perasaan jengkel karena kelebihan beban kerja (Deutsch, 1973: 38). Perasaanperasaan tersebut sewaktu-waktu dapat memicu timbulnya kemarahan. Keadaan tersebut akan mempengaruhi seseorang dalam melaksanakan kegiatannya secara langsung, dan dapat menurunkan produktivitas kerja organisasi secara tidak langsung dengan melakukan banyak kesalahan yang disengaja maupun tidak disengaja. Dalam suatu organisasi, kecenderungan terjadinya konflik, dapat disebabkan oleh suatu perubahan secara tiba-tiba, antara lain: kemajuan teknologi baru, persaingan ketat, perbedaan kebudayaan dan sistem nilai, serta berbagai macam kepribadian individu.
Salah satu lokasi yang rentan akan konflik adalah organisasi. Organisasi merupakan wadah di mana banyak orang berkumpul dan saling berinteraksi. Organisasi juga terbentuk karena adanya kesamaan misi dan visi yang ingin dicapai. Dari sini setiap individu atau unsur yang terdapat di dalam organisasi tersebut secara langsung maupun tidak langsung harus memegang teguh apa yang menjadi pedoman dan prinsip di dalam organisasi tersebut, sehingga untuk mencapai visi dan menjalankan misi yang digariskan dapat berjalan dengan baik.

Seiring berjalannya waktu, di dalam organisasi kerap terjadi konflik. Baik konflik internal maupun konflik eksternal antar organisasi. Konflik yang terjadi kadang kala terjadi karena permasalahan yang sangat remeh temeh. Namun justru dengan hal yang remeh temeh itulah sebuah organisasi dapat bertahan lama atau tidak. Mekanisme ataupun manajemen konflik yang diambil pun sangat menentukan posisi organisasi sebagai lembaga yang menjadi payungnya. Kebijakan-kebijakan dan metode komunikasi yang diambil sangat mempengaruhi keberlangsungan sebuah organisasi dalam mempertahankan anggota dan segenap komponen di dalamnya.

Menurut Deutsch (1973), ada beberapa definisi konflik jika dilihat dari sudut pandang organisasi. Yang pertama, konflik didefinisikan sebagai situasi yang terjadi ketika ada perbedaan pendapat atau perbedaan cara pandang di antara beberapa orang, kelompok atau organisasi. Kemudian sikap saling mempertahankan diri sekurang-kurangnya di antara dua kelompok, yang memiliki tujuan dan pandangan berbeda, dalam upaya mencapai satu tujuan sehingga mereka berada dalam posisi oposisi, bukan kerjasama. Yang terakhir konflik sebagai suatu perselisihan atau perjuangan yang timbul bila keseimbangan antara perasaan, pikiran, hasrat, dan perilaku seseorang terancam. Sementara menurut Douglass dan Bevis (1979), Konflik adalah perjuangan di antara kekuatan-kekuatan interdependen. 


\section{Konflik dan Negosiasi dari Sudut Pandang Arsitektur}

Pandangan mengenai konflik dan negosiasi dalam arsitektur sendiri baru muncul pada awal perkembangan postmodern. Menurut Jencks (1997: 3), arsitektur postmodern memungkinkan para kreatornya untuk mempersatukan sekaligus mempertarungkan konsep-konsep arsitektur yang telah ada sekaligus memodifikasi struktur serta bahan bangunan yang digunakan. Bentuk bangunan sendiri pada akhirnya merupakan perpaduan asimetris karena membebaskan kreatornya dari struktur yang secara ketat mengikat mereka. Makna estetika kemudian dibawa ke ranah yang lebih jauh dengan cara menabrakkan konsep-konsep yang dulunya tabu untuk digunakan bersamaan.

Konflik antara material bangunan serta struktur dan bentuk ternyata merambah menuju sebuah kondisi yang lebih kompleks, seperti yang dinyatakan oleh Jencks (1997: 8). His main drift, however, is aesthetic: for him, complexity represents a psychological and social advance over simplicity, an evolution of culture and urbanism to cope with contradictory problems such as the conflict between the inside and outside pressures on a building.

$\begin{array}{cr}\text { Kompleksitas } & \text { arsitektur } \\ \text { postmodern memunculkan sebuah }\end{array}$
representasi psikologis sekaligus sosial yang memadukan antara masalah-masalah kontradiktif dari suatu bangunan. Sebuah karakteristik bangunan sengaja mengakomodasi komponen-komponen yang pada masa arsitektur modern dianggap sebagai konflik yang tidak mungkin dipertemukan. Tema-tema kultural bangunan antara yang simpel dan rumit dipersatukan dalam sebuah monumen, inilah bentuk negosiasi arsitektural bangunan postmodern.

Lebih lanjut Jencks (1997: 27) menjelaskan bahwa arsitek lain yaitu Venturi berusaha menjelaskan negosiasi ini melalui sistem dasar operasional antara arsitektur dan urbanisme. Venturi's book was titled 'Complexity and Contradiction' because it uncovered the basic oppositional system between architecture and urbanism, fundamental conflicts which have to be faced, not suppressed.

Pendekatan postmodern dalam arsitektur mengijinkan penabrakan sesuatu yang dianggap konflik dalam sudut pandang arsitektur modern seperti warna kontras dalam sebuah kesan bangunan.

Inti dari sebuah bentuk bangunan dalam kerangka pemikiran postmodern ada pada keseluruhannya. Sebuah bangunan yang di dalamnya "berkonflik" tidak lantas membuat bangunan itu menjadi tidak fungsional atau tidak menemukan karakternya. Setiap konflik dalam bangunan harusnya memiliki "tugas" untuk mempersatukan secara keseluruhan demi membentuk makna integral sebuah bangunan. Seperti yang disampaikan Jencks (1997: 29). Several of the most important conflicting forces are represented and fight it out, symphonically, on the five facades. And yet the building still has, as he says it should, 'an obligation towards the difficult whole'.

Walaupun tidak semua bangunan bisa melakukan hal tersebut. Pada intinya karakter bangunan yang kontradiktif dan berkonflik bisa dinegosiasikan melalui bentuk dan fungsi dasar bangunan yang diciptakan oleh arsitek. Seperti yang diungkapkan oleh Jencks (1997: 35). However, most building tasks which involve many conflicting functions, different taste cultures and new and old fabric, demand a more complex response. The same is true of most art and rhetorical forms: the novel and film thrive on complicated twists in plot and conflicting characters and cultures.

Penyelesaian konflik melalui negosiasi bentuk dan fungsi bangunan pada arsitektur postmodern pada dasarnya merupakan suatu keniscayaan. Namun konflik yang ada tidak untuk dibenturkan melainkan dikreasikan untuk diakomodasi dalam bentuk bangunan yang integral. 


\section{Konflik dari Negosiasi Sudut Pandang Sosiologi}

Menggunakan perspektif sosiologi, memang ada cabang teori yang membahas khusus tentang konflik. Ranah konflik ini sendiri awalnya diberangkatkan dari analisis dialektika Marx terhadap masyarakat kapitalisme. Teori konflik adalah teori yang memandang bahwa perubahan sosial tidak terjadi melalui proses penyesuaian nilai-nilai yang membawa perubahan, tetapi terjadi akibat adanya konflik yang menghasilkan kompromi-kompromi yang berbeda dengan kondisi semula (Ritzer dan Goodman, 2001: 14). Teori ini didasarkan pada pemilikan sarana-sarana produksi sebagai unsur pokok pemisahan kelas dalam masyarakat.

Teori konflik muncul sebagai reaksi dari munculnya teori struktural fungsional. Pemikiran yang paling berpengaruh atau menjadi dasar dari teori konflik ini adalah pemikiran Karl Marx. Pada tahun 1950-an dan 1960-an, teori konflik mulai merebak. Teori konflik menyediakan alternatif terhadap teori struktural fungsional. Pada saat itu Marx mengajukan konsepsi mendasar tentang masyarakat kelas dan perjuangannya. Marx tidak mendefinisikan kelas secara panjang lebar tetapi ia menunjukkan bahwa dalam masyarakat, pada abad ke-19 di Eropa di mana dia hidup, terdiri dari kelas pemilik modal (borjuis) dan kelas pekerja miskin sebagai kelas proletar.

Kedua kelas ini berada dalam suatu struktur sosial hirarkis, kaum borjuis melakukan eksploitasi terhadap kaum proletar dalam proses produksi. Eksploitasi ini akan terus berjalan selama kesadaran semu eksis (false consiousness) dalam diri proletar, yaitu berupa rasa menyerah diri, menerima keadaan apa adanya, tetap terjaga. Ketegangan hubungan antara kaum proletar dan kaum borjuis mendorong terbentuknya gerakan sosial besar, yaitu revolusi. Ketegangan tersebut terjadi jika kaum proletar telah sadar akan eksploitasi kaum borjuis terhadap mereka. Menurut pandangan Marx, dalam proses dialektika ini tidak dimungkinkan adanya negosiasi dalam penyelesaian konflik. Konflik antar kelas hanya bisa diselesaikan secara praktis melalui revolusi.

Ada beberapa asumsi dasar dari teori konflik ini. Teori konflik merupakan anti tesis dari teori struktural fungsional, dimana teori struktural fungsional sangat mengedepankan keteraturan dalam masyarakat. Teori konflik melihat pertikaian dan konflik dalam sistem sosial. Teori konflik melihat bahwa di dalam masyarakat tidak akan selamanya berada pada keteraturan. Buktinya dalam masyarakat manapun pasti pernah mengalami konflik-konflik atau ketegangan-ketegangan.

Kemudian teori konflik juga melihat adanya dominasi, koersi, dan kekuasaan dalam masyarakat. Teori konflik juga membicarakan mengenai otoritas yang berbeda-beda. Otoritas yang berbeda-beda ini menghasilkan superordinasi dan subordinasi. Perbedaan antara superordinasi dan subordinasi dapat menimbulkan konflik karena adanya perbedaan kepentingan. Teori konflik juga mengatakan bahwa konflik itu perlu agar terciptanya perubahan sosial. Ketika struktural fungsional mengatakan bahwa perubahan sosial dalam masyarakat itu selalu terjadi pada titik ekulibrium, teori konflik melihat perubahan sosial disebabkan karena adanya konflikkonflik kepentingan. Namun pada suatu titik tertentu, masyarakat mampu mencapai sebuah kesepakatan bersama. Di dalam konflik, selalu ada negosiasi-negosiasi yang dilakukan sehingga terciptalah suatu konsensus.

Menurut Raho (2007: 56) penyebab konflik dalam sebuah masyarakat modern antara lain disebabkan oleh:

1. Semakin tidak merata distribusi sumber-sumber di dalam suatu sistem, akan semakin besar konflik kepentingan antara segmen dominan atau lemah.

2. Segmen-segmen yang lebih lemah (subordinate) semakin menyadari akan kepentingan-kepentingan kolektif mereka maka akan semakin besar 
kemungkinannya mereka itu akan mempertanyakan keabsahan distribusi sumber-sumber yang tidak merata.

3. Segmen-segmen yang lemah dalam suatu sistem semakin sadar akan kepentingan-kepentingan kelompok mereka maka semakin besar kemungkinan mereka mempersalahkan keabsahan distribusi sumber-sumber dan semakin besar pula kemungkinannya mereka mengorganisir untuk memulai konflik secara terang-terangan terhadap segmen-segmen dominan suatu sistem.

4. Apabila segmen-segmen subordinate semakin dipersatukan oleh keyakinan umum dan semakin berkembang struktur kepemimpinan politik mereka, maka segmen-segmen dominan dan segmen-segmen yang dikuasai yang lebih lemah akan terpolarisasi.

Lebih jauh Raho menjelaskan tiga tahapan berkembangnya suatu konflik:

1. Latent Tension (unreal conflict), konflik masih dalam bentuk kesalahpahaman antara satu dengan lainnya, tetapi antara pihak yang bertentangan belum terlibat dalam konflik.

2. Nascent Conflict, konflik mulai tampak dalam bentuk pertentangan meskipun belum menyertakan ungkapanungkapan ideologis dan pemetaan terhadap pihak lawan secara terorganisir.

3. Intensified Conflict, konflik berkembang dalam bentuk yang terbuka disertai dengan radikalisasi gerakan di antara pihak yang saling bertentangan dan masuknya pihak ketiga ke dalam arena konflik.

Menurut teori konflik, masyarakat pada dasarnya disatukan dengan "paksaan". Maksudnya, keteraturan yang terjadi di masyarakat sebenarnya karena adanya paksaan (koersi). Oleh karena itu, teori konflik lekat hubungannya dengan dominasi, koersi, dan power. Terdapat dua tokoh sosiologi modern yang berorientasi serta menjadi dasar pemikiran pada teori konflik, yaitu Lewis A. Coser dan Ralf Dahrendorf.

Menurut Coser, (dalam Poloma, 1994: 72) konflik dapat merupakan proses yang bersifat instrumental dalam pembentukan, penyatuan dan pemeliharaan struktur sosial. Konflik dapat menempatkan dan menjaga garis batas antara dua atau lebih kelompok. Konflik dengan kelompok lain dapat memperkuat kembali identitas kelompok dan melindunginya agar tidak lebur ke dalam dunia sosial sekelilingnya. Seluruh fungsi positif konflik tersebut dapat dilihat dalam ilustrasi suatu kelompok yang sedang mengalami konflik dengan kelompok lain. Misalnya, pengesahan pemisahan gereja kaum tradisional (yang mempertahankan praktek-praktek ajaran katolik pra-Konsili Vatican II) dan gereja Anglo-Katolik (yang berpisah dengan gereja Episcopal mengenai masalah pentahbisan wanita). Perang yang terjadi bertahun-tahun yang terjadi di Timur Tengah telah memperkuat identitas kelompok Negara Arab dan Israel.

Coser melihat katup penyelamat berfungsi sebagai jalan ke luar yang meredakan permusuhan, yang tanpa itu hubungan-hubungan di antara pihak-pihak yang bertentangan akan semakin menajam. Katup Penyelamat (savety-value) ialah salah satu mekanisme khusus yang dapat dipakai untuk mempertahankan kelompok dari kemungkinan konflik sosial. Katup penyelamat merupakan sebuah institusi pengungkapan rasa tidak puas atas sebuah sistem atau struktur. Contoh: Badan Perwakilan Mahasiswa atau panitia kesejahteraan Dosen. Lembaga tersebut membuat kegerahan yang berasal dari situasi konflik tersalur tanpa menghancurkan sistem tersebut.

Menurut Coser konflik dibagi menjadi dua, yaitu:

1. Konflik Realistis, berasal dari kekecewaan terhadap tuntutan-tuntutan khusus yang terjadi dalam hubungan dan dari perkiraan kemungkinan keuntungan para partisipan, dan yang ditujukan pada obyek yang dianggap 
mengecewakan. Contohnya para karyawan yang mogok kerja agar tuntutan mereka berupa kenaikan upah atau gaji dinaikkan.

2. Konflik Non-Realistis, konflik yang bukan berasal dari tujuan-tujuan saingan yang antagonis, tetapi dari kebutuhan untuk meredakan ketegangan, paling tidak dari salah satu pihak. Coser menjelaskan dalam masyarakat yang buta huruf pembalasan dendam biasanya melalui ilmu gaib seperti teluh, santet dan lainlain. Sebagaimana halnya masyarakat maju melakukan pengkambinghitaman sebagai pengganti ketidakmampuan melawan kelompok yang seharusnya menjadi lawan mereka.

Lebih jauh Coser menjelaskan bahwa konflik pada dasarnya fungsional. Untuk mengelola konflik supaya menjadi produktif diperlukan negosiasi dalam rangka menjembatani kelompok kuasi yang biasanya menimbulkan konflik. Ada tiga proses penyelesaian konflik yang disodorkan oleh Coser.

1. Arbitrasi, merupakan proses negosiasi yang melibatkan pihak ketiga yang memutuskan jalannya konflik dan keputusan yang harus diambil dalam menghentikan konflik.

2. Mediasi, merupakan proses negosiasi yang melibatkan pihak ketiga sebagai mediator yang menjembatani antara pihak-pihak yang berkonflik.

3. Konsiliasi, atau biasa disebut sebagai jalan damai. Merupakan sebuah proses negosiasi yang menyatukan kedua belah pihak serta mengabaikan kepentingan masing-masing untuk mencapai tujuan bersama yang lebih besar.

Bukan hanya Coser saja yang tidak puas dengan pengabaian konflik dalam pembentukan teori sosiologi. Segera setelah penampilan karya Coser, seorang ahli sosiologi Jerman bernama Ralf Dahrendorf menyadur teori kelas dan konflik kelasnya ke dalam bahasa Inggris yang sebelumnya berbahasa Jerman agar lebih mudah difahami oleh sosiolog Amerika yang tidak faham bahasa Jerman saat kunjungan singkatnya ke Amerika Serikat (19571958). Dahrendorf membangun teorinya dengan separuh penerimaan, separuh penolakan, serta memodifikasi teori sosiologi Karl Marx. Seperti halnya Coser, Ralf Dahrendorf mula-mula melihat teori konflik sebagai teori parsial, menganggap teori tersebut merupakan perspektif yang dapat dipakai untuk menganalisis fenomena sosial. Ralf Dahrendorf menganggap masyarakat bersisi ganda, memiliki sisi konflik dan sisi kerja sama.

Teori konflik Ralf Dahrendorf merupakan separuh penerimaan, separuh penolakan, serta modifikasi teori sosiologi Karl Marx. Karl Marx berpendapat bahwa pemilikan dan kontrol sarana-sarana berada dalam satu individu-individu yang sama. Menurut Dahrendorf tidak selalu pemilik sarana-sarana juga bertugas sebagai pengontrol apalagi pada abad kesembilan belas. Bentuk penolakan tersebut ia tunjukkan dengan memaparkan perubahan yang terjadi di masyarakat industri semenjak abad kesembilan belas. Di antaranya:

1. Dekomposisi Modal

Menurut Dahrendorf timbulnya korporasi-korporasi dengan saham yang dimiliki oleh orang banyak, dimana tak seorangpun memiliki kontrol penuh merupakan contoh dari dekomposisi modal.

2. Dekomposisi Tenaga Kerja

Di abad spesialisasi sekarang ini mungkin sekali seorang atau beberapa orang mengendalikan perusahaan yang bukan miliknya, seperti halnya seseorang atau beberapa orang yang mempunyai perusahaan tapi tidak mengendalikanya. Karena zaman ini adalah zaman keahlian dan spesialisasi, manajemen perusahaan dapat menyewa pegawai-pegawai untuk memimpin perusahaanya agar berkembang dengan baik.

3. Timbulnya Kelas Menengah Baru Pada akhir abad kesembilan belas, lahir kelas pekerja dengan susunan yang 
jelas, di mana para buruh terampil berada di jenjang atas sedang buruh biasa berada di bawah.

Penerimaan Dahrendorf pada teori konflik Karl Marx adalah ide mengenai pertentangan kelas sebagai satu bentuk konflik dan sebagai sumber perubahan sosial. Kemudian dimodifikasi oleh berdasarkan perkembangan yang terjadi akhir-akhir ini. Dahrendorf mengatakan bahwa ada dasar baru bagi pembentukan kelas, sebagai pengganti konsepsi pemilikan sarana produksi sebagai dasar perbedaan kelas itu. Menurut Dahrendorf hubungan-hubungan kekuasaan yang menyangkut bawahan dan atasan menyediakan unsur bagi kelahiran kelas.

Dahrendorf mengakui terdapat perbedaan di antara mereka yang memiliki sedikit dan banyak kekuasaan. Perbedaan dominasi itu dapat terjadi secara drastis. Tetapi pada dasarnya tetap terdapat dua kelas sosial yaitu, mereka yang berkuasa dan yang dikuasai. Dalam analisisnya Dahrendorf menganggap bahwa secara empiris, pertentangan kelompok mungkin paling mudah dianalisis bila dilihat sebagai pertentangan mengenai legitimasi hubungan-hubungan kekuasaan. Dalam setiap asosiasi, kepentingan kelompok penguasa merupakan nilai-nilai yang merupakan ideologi keabsahan kekuasaannya, sementara kepentingankepentingan kelompok bawah melahirkan ancaman bagi ideologi ini serta hubunganhubungan sosial yang terkandung di dalamnya.

Contoh: Kasus kelompok minoritas yang pada tahun 1960-an kesadarannya telah memuncak, antara lain termasuk kelompok-kelompok kulit hitam, wanita, suku Indian dan Chicanos. Kelompok wanita sebelum tahun 1960-an merupakan kelompok semu yang ditolak oleh kekuasaan di sebagian besar struktur sosial di mana mereka berpartisipasi. Pada pertengahan tahun 1960-an muncul kesadaran kaum wanita untuk menyamakan derajatnya dengan kaum laki-laki.
Lebih jauh Dahrendorf menjelaskan jika konflik dalam masyarakat sosial pada dasarnya merupakan sebuah proses dalam rangka mencari titik keseimbangan melalui perubahan sosial. Konflik sendiri menyediakan sebuah dinamika dalam masyarakat yang nantinya akan mengarahkan mereka menuju titik kesempurnaan suatu peradaban. Sehingga konflik harus dikelola supaya menjadi fungsional, karena sifat dasar konflik pada dasarnya bukan pada perebutan kekuasaan.

\section{Konflik dari Negosiasi Sudut Pandang Teknologi}

Satu pertanyaan mendasar mengenai keberadaan teknologi dalam kaitannya dengan kultur, yaitu apakah sebuah teknologi memiliki posisi netral terkait dengan eksistensinya di dalam masyarakat (Pacey, 2000:3). Beberapa ilmuwan menganggap bahwa keberadaan teknologi di dalam suatu masyarakat memiliki sifat yang netral dikarenakan penemuannya yang berbasis ilmu pengetahuan. Namun tidak dapat dipungkiri bahwa lahirnya sebuah teknologi selalu memiliki hubungan dengan kebutuhan masyarakat. Sehingga netralitas kemunculan sebuah teknologi masih bisa diperdebatkan hingga kini.

Jika dilihat dari satu sudut pandang, pada dasarnya teknologi, secara universal, dianggap netral dalam tataran tidak memiliki keberpihakan pada kultur, moral maupun politik. Yang membuat teknologi menjadi berpihak adalah individu-individu di dalam sebuah kultur tertentu yang memodifikasi suatu bentuk teknologi menjadi sesuai dengan kebutuhan maupun kepentingan masyarakatnya. Jadi dalam tataran dunia yang lebih luas, muncul sebuah argumen bahwa teknologi memiliki sifat yang amoral (tidak memiliki keterkaitan sama sekali dengan nilai-nilai yang dianut manusia), sebuah alat yang dapat digunakan untuk kebaikan maupun keburukan.

Contohnya teknologi 3G dalam telepon seluler yang didesain untuk memudahkan akses informasi bagi 
penggunanya dimanapun mereka berada. Dari satu contoh ini dapat dijawab pertanyaan mengenai netralitas teknologi. Jika dilihat dari konstruksi dasar sebuah instrumen yang bekerja berdasarkan prinsip-prinsip fisika atau matematis maka bisa dinyatakan bahwa teknologi $3 \mathrm{G}$ dalam telepon seluler memang netral. Namun pada saat teknologi ini diletakkan pada jaringan aktivitas manusia yang melingkupi keberadaannya, yang melibatkan kegunaan secara praktis, perannya sebagai simbol status dan lain sebagainya, maka jawabannya jelas, teknologi $3 \mathrm{G}$ dalam telepon seluler tidak netral.

Pertanyaan selanjutnya yang harus dijawab terkait dengan eksistensi sebuah teknologi adalah pendefinisian teknologi maupun praktik penggunaan teknologi secara baku. Biasanya wacana mengenai hal tersebut dikaitkan dengan hubungan sosial dan kontrol sosial sebuah teknologi yang memiliki kecenderungan untuk fokus pada suatu organisasi tertentu. Yang menekankan pada perencanaan dan administrasi, manajemen penelitian, sistem regulasi polusi dan bentuk kerusakan lainnya. Terlalu seringnya pembahasan mengenai technology-practice seputar halhal tersebut menyebabkan hal-hal lain semacam nilai-nilai personal dan pengalaman individu dalam technical work diabaikan.

Padahal jika dilihat lebih jauh lagi, penggunaan teknologi berdasarkan nilainilai personal akan terkait erat dengan pemanfaatanya untuk kebaikan ataukah sebaliknya. Sehingga ada pemisahan antara istilah-istilah yang digunakan dalam menjelaskan teknologi. Dua istilah yang dipisahkan definisinya adalah "technical" dan "technological". Istilah 'technological' didefinisikan sebagai basis fundamental sebuah penemuan atau inovasi, sementara 'technical' didefinisikan sebagai cara yang digunakan untuk memecahkan sebuah masalah menggunakan teknologi. Sehingga jika kita bicara mengenai nuklir, teknologi adalah dasar-dasar ilmuah sebuah nuklir yang tidak memiliki hubungan dengan penggunaannya, sementara teknikal adalah penggunaan nuklir untuk, katakanlah, pembangkit tenaga listrik atau bahkan menghancurkan sebuah negara.

Berdasarkan penjelasan tersebut muncul sebuah proposisi mengenai keterkaitan teknologi dengan sikap-sikap yang dimiliki individu pengguna teknologi sebagai bagian dari masyarakat. Banyak ilmuwan yang bekerja untuk mengembangkan teknologi merasa kesulitan untuk memprediksi permasalahan kultural yang akan muncul akibat penemuannya dikarenakan kondisi masyarakat yang sangat beragam antara satu dengan lainnya. Belum lagi keterkaitan dengan aspek organisasional dari sebuah teknologi, utamanya tugas spesifik dari suatu organisasi yang berhubungan konotatif dengan kondisi politik.

Salah satu faktor yang memiliki hubungan erat dengan pertumbuhan penggunaan sebuah teknologi adalah organisasi yang diberikan legitimasi untuk mendiseminasikan teknologi tersebut. Semakin baik manajemen sebuah organisasi yang mendiseminasikan teknologi berimplikasi positif terhadap pertumbuhan penggunaan teknologi itu sendiri. Komponen dalam organisasi yang akan mendukung proyek diseminasi teknologi itu antara lain pekerja, kebijakan-kebijakan organisasional, budaya organisasi dan efektivitas serta efisiensi kinerja organisasi.

Saat melihat diagram pertumbuhan penggunaan teknologi ada beberapa sudut pandang yang dapat digunakan. Salah satu sudut pandang yang biasa digunakan adalah sudut pandang linear, dimana pertumbuhan penggunaan suatu teknologi dianggap berhasil jika grafik yang dihasilkan membentuk sebuah garis yang secara stabil merambat ke atas. Namun, satu garis ini dianggap tidak dapat mewakili keberhasilan pertumbuhan penggunaan suatu teknologi. Kadang kala diperlukan sudut pandang yang lebih luas terkait dengan kondisi sosio-kultural dimana teknologi tersebut didiseminasikan.

Seperti yang dinyatakan oleh Dahrendorf (1986), mengukur sebuah pertumbuhan penggunaan teknologi sudah 
saat tidak hanya berdasarkan garis linier yang diperoleh dari kuantifikasi penggunaannya. Karena pada dasarnya teknologi diciptakan untuk memudahkan hidup manusia. Jika pertumbuhan teknologi hanya dilihat dari kuantifikasi penggunanya namun tidak dilihat bagaimana para adopter tersebut menggunakan teknologi untuk memudahkan hidupnya niscaya teknologi akan kehilangan esensinya.

Contoh di Indonesia adalah konversi minyak tanah menjadi gas. Pemerintah mengeluarkan kebijakan baru, setiap anggota masyarakat 'dipaksa' menggunakan kompor gas mini dengan tabung elpiji $3 \mathrm{~kg}$. Secara grafis dapat dilihat bahwa pertumbuhan pengguna kompor gas ini menanjak secara linear. Namun banyak di daerah-daerah terpencil Indonesia yang menyimpan tanpa memanfaatkan teknologi tersebut karena dirasa makin mengganggu ritme kehidupannya.

Sehingga dapat disimpulkan bahwa untuk mengukur pertumbuhan penggunaan sebuah teknologi tidak cukup hanya dengan kuantifikasi penggunanya yang menanjak garis linearnya. Tapi kita juga harus bisa melihat lebih jauh, penggunaan teknologi tersebut mencapai kualitas yang seperti apa. Hal ini diperlukan untuk memenuhi esensi teknologi yang akan memudahkan hidup manusia.

Teknologi sendiri adalah salah satu hal yang bisa menyebabkan konflik sekaligus memediasi negosiasi. Seperti yang disampaikan oleh Innis (Loon, 2008: 22), setiap munculnya teknologi pada akhirnya akan menghasilkan bias antara penguasa teknologi, individu yang mampu mengakses teknologi, serta pengguna teknologi itu sendiri. Innis mendefinisikan bias sebagai "Internally motivated distortions in the translation from original ideas and intentions into the message-asreceived". Bias inilah yang pada akhirnya memicu konflik karena terkait erat dengan reproduksi strukturalnya yaitu kekayaan, kekuasaan dan pengetahuan.

Informasi sendiri pada akhirnya akan dikomodifikasi sehingga timbul kesenjangan informasi bagi yang rich information dan poor information. Mengingat teknologi melakukan proses seleksi akses informasi seperti yang disampaikan oleh McLuhan (Loon, 2008: 42), mencakup:

1. Knowing that the information or information service is available.

2. Owning or having access to the equipment necessary to connect to the information source (e.g., computer, television, telephone, software, modem), service is available,

3. Gaining access to the information service (e.g., afford cable or online charges), and

4. Knowing how to operate the necessary hardware and software (e.g., be "computer literate").

Sehingga pada akhirnya konflik akan timbul pada saat terjadi clash antara pihak yang bisa mengakses informasi karena memiliki teknologi dengan yang tidak. Namun teknologi tidak selamanya buruk mengingat proses negosiasi juga bisa dijalankan menggunakan perantara teknologi.

\section{SIMPULAN}

Ilmu komunikasi, arsitektur, sosiologi, dan teknologi memiliki hakekat dasar yang berbeda. Arsitektur pada intinya adalah hasil upaya manusia menciptakan lingkungan yang utuh untuk menampung kebutuhan manusia bertempat tinggal, berusaha, atau bersosial budaya. Sosiologi, di sisi lain adalah ilmu kemasyarakatan yang mempelajari struktur sosial dan proses-proses sosial termasuk perubahan sosial. Sedangkan komunikasi secara ontologis berarti ilmu yang mempelajari "interaksi." Adapun teknologi berbicara tentang bagaimana manusia memodifikasi lingkungan alam atau sumber daya alam agar sesuai dengan tujuannya.Meskipun berbeda tetapi ilmu-ilmu tersebut saling mempengaruhi baik secara tema kajian, teori, maupun metoda penelitian. 
Bagaimana ilmu-ilmu tersebut saling mempengaruhi terlihat ketika mereka membahas "konflik" dan "negosiasi." Tetapi karena secara hakekat dasar keilmuan mereka berbeda, fokus utama ketiganya di dalam membahas "konflik dan "negosiasi" memiliki penekanan yang berbeda. Pada kajian mengenai konflik, misalnya, komunikasi menekankan bagaimana interaksi (dengan individu lain maupun teks) yang dilakukan manusia di dalam menghadapi konflik, arsitektur menekankan kepada pengkomunikasian konflik melalui desain bangunan yang kontras dan juga perbedaan makna antara arsitek dengan klien dan juga penikmat/pengamat bangunan, dan antropologi lebih menekankan pada terjadinya suatu peristiwa konflik yang disebabkan oleh perbedaan kondisi sosial dan budaya. Adapun teknologi memandang konflik sebagai akibat dari penggunaan nilai-nilai personal akan terkait erat dengan pemanfaatanya untuk kebaikan ataukah sebaliknya

\section{DAFTAR PUSTAKA}

Susanto. Astrid S. (1985). Pengantar Sosiologi dan Perubahan Sosial. Bandung: Bina Cipta.

Arifin, Syamsul. (2009). Studi Agama: Perspektif Sosiologis dan Isu-isu Kontemporer. Malang: UMM Press.

Bernard, Raho. (2007). Teori Sosiologi Modern. Jakarta: Prestasi Pustaka Publisher.

Dahrendorf, Ralf. (1986). Konflik dan Konflik Kelas dalam Masyarakat Industri. Jakarta: CV. Rajawali.

Deutsch, M. (1973). Conflicts: Productive and destructive. In Conflict Resolution Through Communication, edited by F. E. Jandt. New York: Harper \& Row.
Grosz, Elizabeth. (2001). Architecture From the Outside: Essays on Virtual and Real Space. USA: MIT Publishers.

Guntoro, Agus. (2008). Kosmologi dalam Arsitektur. Arya Ronald (Ed.). Kekayaan dan Kelenturan Arsitektur. Surakarta: MUP

Hutama, David. (2007). Mata Kuliah Teknik Komunikasi Arsitektur di dalam Pendidikan Arsitektur. Jurnal Ilmiah Arsitektur. Volume 4 No.1.

Jencks, Charles. (1997). The Architecture of Jumping Universe. New York : John Wiley and Sons.

Littlejohn, Stephen W. (2000). Theories of Human Communication. $7^{\text {th }}$ Edition. Belmont: Wadsworth

Loon, Joost van. (2008). Media Technology: Critical Perspectives. London: Open University Press.

Margaret, M. Poloma. (1994). Sosiologi Kontemporer. Jakarta: PT Raja Grafindo Persada.

McLuhan, Marshall. (1964). Understanding Media: The Extension of Man.

Narwoko, Dwi, dan Bagong Suyanto. (2006). Sosiologi: Teks Pengantar dan Terapan. Jakarta: Kencana Prenada.

Pacey, Arnold. (2000). The Culture of Technology. MIT Press.

Parsons, Talcott. (1991). The Social System. London: Routledge.

Ritzer, George and Goodman, Douglas J. (2001). Teori Sosiologi Modern. Edisi Keenam. Jakarta: Penerbit Kencana

Stewart J. \& Logan C. (1993). Together: Communicating Interpersonally. 4th Edition. New York: McGrawHill. 